\title{
Dosis Pupuk Fosfat Terhadap Pertumbuhan Dan Hasil Beberapa Jagung Hibrida
}

\author{
Herlina Mega Puspitasari ${ }^{1}$ ), Ahmad Yunus ${ }^{2}$ ), Dwi Harjoko ${ }^{2}$ )
}

\begin{abstract}
Corn (Zea mays) is a primary source of food after rice, considered as cerealia crops. This research to analyzing about growth and yield of several variety of hybrid corn on phospat fertilizer dosage giving because in Indonesia the land is nutrient-deficient phospat. This research has been held on June until October 2017 in Kecamatan Piyungan, Kabupaten Bantul, Daerah Istimewa Yogyakarta. Plan which used in this research are Split Plot Design which consist of 2 factors which observed three varieties of hybrid corn (ABCD, EFGH and IJKL) as main plot and phospat fertilizer dosage giving $\left(0,100\right.$ and 150 kilogram ha $\left.^{-1}\right)$ as sub plot which repeated three times. Research fact found that the topography of the research field is $40 \%$ of the plains with a slope of less than $2 \%$ and $60 \%$ of hilly areas with a slope above $40.1 \%$ and the type of the soil is regosol with the highest temperature recorded at the study site was $32^{\circ} \mathrm{C}$ with the lowest temperature of $23^{\circ} \mathrm{C}$, then phospat fertilizer dosage is strongly influence the growth and yield of each hybrid corn variety. The best dosage of fosfat fertilizer for corn growth is 150 kilogram ha $^{-1}$ on each variety, which are ABCD variety, EFGH, and IJKL. The best habit of the growth and yield of hybrid corn is on the phospat fertilizer dosage giving at 150 kilogram ha $^{-1}$ with variety EFGH.
\end{abstract}

Keywords: Zea mays, SP36, Variety

\section{PENDAHULUAN}

Jagung (Zea mays) merupakan bahan pangan utama kedua setelah beras dan termasuk tanaman serealia yang biasa tumbuh hampir di seluruh dunia. Jagung dijadikan bahan pangan utama pada beberapa daerah di Indonesia. Selain sebagai bahan pangan, jagung juga dikenal sebagai salah satu bahan pakan ternak dan industri (Bakhri 2007). Produktivitas di lahan petani sangat beragam, berkisar antara 3,2-8 t/ha (Yasin et al. 2014). Selama ini Indonesia juga telah mengekspor 3,36 juta ton pada 2000 namun menurun menjadi 1,67 juta ton pada 2003 dan meningkat lagi menjadi 3,67 juta ton pada 2004. Ekspor jagung terutama ke Hongkong, Malaysia, Jepang, Filipina, dan Thailand (BPS 2004). Sehingga perlu peningkatan ekspor untuk menambah pendamapatan negara.

Penggunaan varietas unggul berperan penting dalam upaya peningkatan produksi dan produktivitas jagung. Secara umum dikelompokkan menjadi dua jenis benih varietas unggul jagung, yaitu: jagung hibrida dan jagung komposit. Jagung hibrida mempunyai potensi untuk dikembangkan terutama dalam menunjang peningkatan produktivitas nasional. Banziger et al. (2000) dan O'Neill et al. (2004) menyatakan varietas unggul baru jagung hibrida diperoleh melalui program pemuliaan tanaman yang berkelanjutan.

\footnotetext{
1) Mahasiswa Program Studi Agroteknologi Fakultas Pertanian UNS, Surakarta

2) Staf Pengajar Program Studi Agroteknologi Fakultas

Pertanian UNS, Surakarta
}

Author Contact: herlinamega15@gmail.com
Selain memperhatikan varietas, daya hasil jagung hibrida akan semakin tinggi apabila pemupukan dilakukan secara tepat dan benar.Pemberian pupuk pada tanaman jagung, dapat diberikan dengan jenis pupuk organik dan pupuk anorganik. Salah satu pupuk anorganik adalah pupuk fosfat. Menurut Hartanto (2009), pupuk fosfat alam mengandung fosfor (P) merupakan salah satu dari tiga unsur makro atau esensial selain nitrogen dan kalium, yang dibutuhkan untuk pertumbuhan tanaman. Sebagian besar tanah di Indonesia yaitu $68 \%$ dari total lahan termasuk tanah yang memiliki defisiensi unsur hara $P$ (Dierolf et at. 2001). Menurut Winks (1990), unsur hara $P$ merupakan salah satu faktor pembatas pertumbuhan jagung. Upaya untuk mengatasi masalah defisiensi P dilakukan dengan pemupukan $\mathrm{P}$. Oleh karena itu perlu dilakukan penelitian mengenai dosis pupuk fosfat terhadap pertumbuhan dan hasil beberapa jagung hibrida.

\section{BAHAN DAN METODE}

Penelitian dilaksanakan pada bulan Juni sampai September 2017 di Kecamatan Piyungan, Kabupaten Bantul, Daerah Istimewa Yogyakarta yang berjenis tanah regosol dan Laboratorium Ekologi dan Manajemen Produksi Tanaman Fakultas Pertanian Universitas Sebelas Maret Surakarta. Bahan yang digunakan meliputi benih jagung hibrida varietas $A B C D$ dan EFGH, pupuk urea dan pupuk SP36.

Rancangan yang digunakan dalam penelitian ini adalah Rancangan Petak Terbagi (Split Plot Design) yang terdiri dari 2 faktor yang diteliti yaitu tiga varietas jagung hibrida (ABCD, EFGH dan IJKL) sebagai main plot dan pemberian dosis pupuk fosfat $(0,100$ dan 150 kilogram ha ${ }^{-1}$ ) sebagai sub plot yang diulang sebanyak tiga kali sehingga diperoleh 9 perlakuan. Tahapan pelaksanaan penelitian meliputi persiapan lahan, 
persiapan bahan tanam, penanaman, pemupukan, penyiraman, penyulaman, penjarangan, penyiangan, pemanenan. Data pengamatan dianalisis dengan analisis ragam pada taraf $5 \%$ dan apabila beda nyata dilanjutkan dengan DMRT taraf 5\%

\section{HASIL DAN PEMBAHASAN}

\section{Kondisi Umum Lahan}

Lahan penelitian termasuk dataran rendah dengan ketinggian 80 meter diatas permukaan laut. Letak geografis daerah ini terletak antara $110^{\circ} 29^{\prime} 03.8^{\prime \prime}$ Bujur Timur dan $7^{\circ} 49^{\prime} 22,6^{\prime \prime}$ Lintang Selatan dengan jenis tanah regosol. Topografi lahan penelitian berupa $40 \%$ dataran dengan kemiringan kurang dari $2 \%$ dan $60 \%$ daerah perbukitan dengan kemiringan diatas $40,1 \%$.

\section{Tinggi tanaman}

Tinggi tanaman merupakan salah satu variabel yang diukur pada penelitian ini. Tinggi tanaman dihitung dari pangkal batang hingga ruas batang terakhir sebelum bunga. Tinggi tanaman merupakan ukuran tanaman yang sering diamati sebagai indikator pertumbuhan maupun sebagai variabel untuk mengukur pengaruh lingkungan atau perlakuan yang diterapkan karena tinggi tanaman merupakan ukuran pertumbuhan yang paling mudah dilihat (Sitompul dan Guritno 1995).

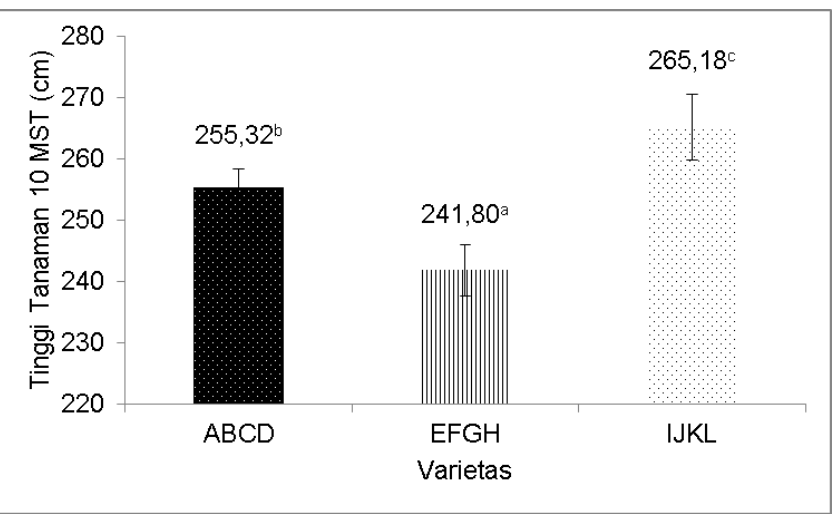

Gambar 1 Pengaruh varietas terhadap tinggi jagung umur 10 MST

Hasil analisis ragam menunjukkan varietas berpengaruh terhadap tinggi tanaman jagung umur 10 MST. Varietas IJKL memiliki rata-rata tinggi tanaman yang paling tinggi yaitu $265,18 \mathrm{~cm}$ diikuti varietas $A B C D$ yaitu 255,32 cm kemudian yang terendah adalah varietas EFGH yaitu 241,80 cm. Menurut Amir et al. (2013), sifat tinggi tanaman dapat dipengaruhi oleh faktor genetik dan lingkungan atau interaksi antar lingkungan dengan genetik. Sejalan dengan Tahir et al. (2013), tinggi tanaman merupakan faktor yang dipengaruhi genetik dan lingkungan, sehingga setiap varietas jagung hibrida mempunyai tinggi tanaman yang berbeda. Hal ini karena tinggi tanaman merupakan faktor genetik yang terkontrol sedangkan pengaruh faktor lingkungan tergantung dari pemilihan varietas tanaman yang tepat yang dapat beradaptasi terhadap kondisi lingkungan setempat yang digunakan.

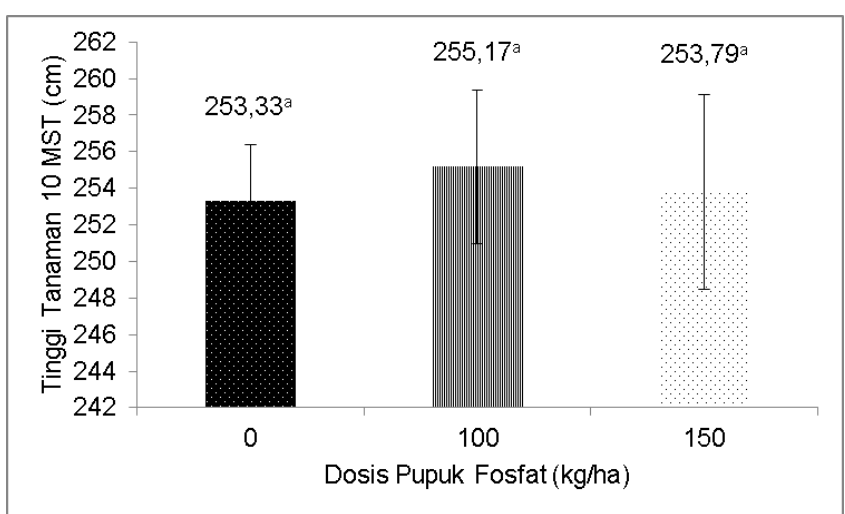

Gambar 2 Pengaruh dosis pupuk fosfat terhadap tinggi jagung umur 10 MST

Pemberian dosis pupuk fosfat tidak dapat meningkatkan tinggi tanaman jagung dimana hasil yang diperoleh dari pemberian dosis pupuk fosfat pada semua dosis memberikan rentang yang hampir sama. Hal ini diduga karena menurut (Idawati 1996) bahwa efisiensi pemupukan $\mathrm{P}$ pada umumnya sangat rendah, yaitu kurang dari 10\%. Hal tersebut disebabkan oleh fiksasi $P$ dalam tanah sehingga unsur $P$ yang diberikan tidak seluruhnya tersedia bagi tanaman. Tingginya fiksasi $P$ dalam tanah menyebabkan penimbunan $P$ dalam tanah dari waktu ke waktu selama pemberian pupuk P dilakukan. Selain itu Sanchez (1992) menyatakan bahwa sebagian besar pupuk $P$ yang tidak terserap oleh tanaman tidak hilang tercuci, tetapi menjadi non labil $P$ yang tidak tersedia bagi tanaman.

\section{Tasseling dan silking}

Salisbury dan Ross (1995) menyatakan bahwa waktu berbunga merupakan variabel pertumbuhan generatif yang diamati. Pembungaan pada tanaman jagung ditandai dengan munculnya kepala-kepala sari dari buliran pada malai bunga jantan dan kemunculan rambut-rambut (kepala-kepala putik) dari kelobot (Golds-worthy dan Fisher 1984).

Tabel 1 Rata-rata tasseling dan silking jagung hibrida pada perlakuan tiga varietas

\begin{tabular}{|c|c|c|c|}
\hline \multirow{2}{*}{ Variabel } & \multicolumn{3}{|c|}{ Varietas } \\
\hline & $A B C D$ & EFGH & IJKL \\
\hline $\begin{array}{l}\text { Tasseling } \\
\text { (HST) }\end{array}$ & $53,12^{a}$ & $55,31^{b}$ & $53,26^{a}$ \\
\hline Silking (HST) & $56,61^{b}$ & $57,36^{\mathrm{C}}$ & $56,05^{\mathrm{a}}$ \\
\hline
\end{tabular}

Keterangan: Angka yang diikuti huruf sama pada baris menunjukkan tidak beda nyata berdasarkan DMRT taraf $5 \%$

Varietas berpengaruh terhadap tasseling dan silking. Tasseling paling lambat menurut hasil pengamatan terlihat pada rata-rata perlakuan varietas EFGH pada 55,31 hari setelah tanam. Berdasarkan hasil pengamatan, rata-rata setelah tiga sampai empat hari bunga jantan (tasseling) muncul maka rambut jagung (silking) juga muncul. Silking paling lambat didapatkan dari EFGH (57,36 HST). Subekti et al. (2008) mengungkapkan bahwa munculnya bunga yang 
lebih awal waktu akan membantu fase awal pengisian biji dalam mengakumulasi pati pada biji dengan sangat cepat sehingga warna biji sudah mulai terlihat, kadar air biji mencapai $80 \%$ dan fase masak fisiologis cepat mencapai berat kering maksimum.

\section{Jumlah baris per tongkol dan panjang tongkol}

Jumlah baris per tongkol dan panjang tongkol masing-masing varietas memberikan hasil yang berbeda, seperti terlihat pada Tabel 2 .

Tabel 2 Rata-rata jumlah baris per tongkol dan panjang tongkol pada varietas yang berbeda

\begin{tabular}{lccc}
\hline \multicolumn{1}{c}{ Variabel } & \multicolumn{3}{c}{ Varietas } \\
\cline { 2 - 4 } & ABCD & EFGH & IJKL \\
\hline $\begin{array}{l}\text { Jumlah baris } \\
\text { per tongkol } \\
\text { (baris) }\end{array}$ & $13,95^{\mathrm{a}}$ & $16,74^{\mathrm{b}}$ & $15,67^{\mathrm{ab}}$ \\
$\begin{array}{l}\text { Panjang } \\
\text { tongkol (cm) }\end{array}$ & $17,49^{\mathrm{a}}$ & $20,91^{\mathrm{b}}$ & $17,33^{\mathrm{a}}$
\end{tabular}

Keterangan: Angka yang diikuti huruf sama pada baris menunjukkan tidak beda nyata berdasarkan DMRT taraf $5 \%$

Jumlah baris per tongkol menunjukkan varietas EFGH memiliki rata-rata jumlah baris per tongkol tertinggi yaitu 16,74. Menurut Rahni (2012), panjang tongkol dan jumlah baris biji per tongkol berhubungan erat dengan jumlah biji per tongkol.

Tabel 3 Rata-rata jumlah baris per tongkol dan panjang tongkol pada pemberian dosis pupuk fosfat

\begin{tabular}{|c|c|c|c|}
\hline \multirow[t]{2}{*}{ Variabel } & \multicolumn{3}{|c|}{$\begin{array}{c}\text { Dosis Pupuk Fosfat (kilogram } \\
\mathrm{ha}^{-1} \text { ) }\end{array}$} \\
\hline & 0 & 100 & 150 \\
\hline $\begin{array}{l}\text { Jumlah baris per } \\
\text { tongkol (baris) }\end{array}$ & $15,15^{a}$ & $15,30^{\mathrm{a}}$ & $15,92^{\mathrm{a}}$ \\
\hline $\begin{array}{l}\text { Panjang tongkol } \\
(\mathrm{cm})\end{array}$ & $17,81^{a}$ & $18,90^{\mathrm{a}}$ & $19,04^{a}$ \\
\hline
\end{tabular}

Keterangan: Angka yang diikuti huruf sama pada baris menunjukkan tidak beda nyata berdasarkan DMRT taraf $5 \%$

Jumlah baris per tongkol dan panjang tongkol yang dihasilkan perlakuan pemberian dosis pupuk fosfat 150 kilogram ha ${ }^{-1}$ cenderung meningkatkan jumlah baris per tongkol dan panjang tongkol dibandingkan dengan perlakuan yang lain. Sejalan dengan Budiman (2004) yang menyatakan bahwa metabolisme tanaman juga akan lebih aktif dengan terserapnya unsur $\mathrm{P}$ sehingga proses pemanjangan, pembelahan dan diferensiasi sel akan lebih baik sehingga peningkatan berat, panjang buah akan terjadi.

\section{Berat tongkol dengan kelobot dan tanpa kelobot}

Mayadewi (2007) menyatakan bahwa peningkatan berat segar tongkol berhubungan erat dengan besarnya fotosintat yang ditranslokasikan ke bagian tongkol.
Hasil berat tongkol dengan kelobot dan tanpa kelobot tersedia pada berikut.

Tabel 4 Rata-rata berat tongkol jagung hibrida dengan kelobot dan tanpa kelobot pada tiga varietas jagung hibrida

\begin{tabular}{lccc}
\hline \multicolumn{1}{c}{ Variabel } & \multicolumn{3}{c}{ Varietas } \\
\cline { 2 - 4 } & ABCD & EFGH & IJKL \\
\hline $\begin{array}{l}\text { Berat tongkol } \\
\text { dengan kelobot } \\
\text { (gram) }\end{array}$ & $255,99^{\mathrm{a}}$ & $286,20^{\mathrm{b}}$ & $282,52^{\mathrm{b}}$ \\
$\begin{array}{l}\text { Berat tongkol } \\
\text { tanpa kelobot } \\
\text { (gram) }\end{array}$ & $238,60^{\mathrm{a}}$ & $266,34^{\mathrm{b}}$ & $259,22^{\mathrm{b}}$ \\
\hline Keterangan: Angka & & & \\
\hline
\end{tabular}

Keterangan: Angka yang diikuti huruf sama pada baris menunjukkan tidak beda nyata berdasarkan DMRT taraf $5 \%$

Berat tongkol tanaman jagung dipengaruhi oleh fotosintesis. Fotosintesis akan meningkat apabila penyerapan energi sinar matahari berlangsung dengan maksimal, sehingga produksi biji dalam jagung juga akan meningkat dan beratnya bertambah (Wardani et al. 2009). Rata-rata berat tongkol dengan kelobot dan berat tongkol tanpa kelobot akibat pengaruh varietas terlihat bahwa berat tongkol dengan kelobot dan berat tongkol tanpa kelobot paling tinggi dijumpai pada perlakuan varietas EFGH dan tidak berbeda nyata dengan IJKL namun berbeda nyata dengan $A B C D$ yang merupakan rata-rata paling rendah.

Tabel 5 Rata-rata berat tongkol jagung hibrida dengan kelobot dan tanpa kelobot pada dosis pupuk fosfat

\begin{tabular}{lccc}
\hline \multirow{1}{*}{ Variabel } & \multicolumn{3}{c}{$\begin{array}{c}\text { Dosis Pupuk Fosfat } \\
\text { (kilogram/ha) }\end{array}$} \\
\cline { 2 - 4 } & 0 & 100 & 150 \\
\hline $\begin{array}{l}\text { Berat tongkol } \\
\text { dengan kelobot } \\
\text { (gram) }\end{array}$ & $266,54^{\mathrm{a}}$ & $255,61^{\mathrm{a}}$ & $302,56^{\mathrm{b}}$ \\
$\begin{array}{l}\text { Berat tongkol } \\
\text { tanpa kelobot } \\
\text { (gram) }\end{array}$ & $249,30^{\mathrm{a}}$ & $237,56^{\mathrm{a}}$ & $277,30^{\mathrm{b}}$ \\
\end{tabular}

Keterangan: Angka yang diikuti huruf sama pada baris menunjukkan tidak beda nyata berdasarkan uji DMRT taraf $5 \%$

Dosis pupuk fosfat dapat meningkatkan berat tongkol jagung. Pemberian dosis pupuk fosfat tertinggi yaitu pada 150 kilogram ha $^{-1}$ memberikan rata-rata berat tongkol dengan kelobot (302,56 gram) dan berat tongkol tanpa kelobot tertinggi (277,30 gram). Kontrol menghasilkan berat yang paling rendah, dikarenakan kontrol digunakan sebagai pembanding pada penelitian ini dan tidak diberi dosis pupuk fosfat, sehingga tanah pada kontrol kekurangan unsur hara. Pertumbuhan suatu tanaman tidak akan tumbuh dengan maksimal jika kandungan unsur hara kurang dari yang dikehendaki oleh suatu tanaman (Sutedjo 1992). 


\section{Berat biji pipilan kering, berat 100 biji dan nilai indeks panen}

Berat 100 biji secara tidak langsung dapat mempengaruhi hasil tanaman berupa berat pipilan kering. (Kusnadi 2000).

Tabel 6. Rata-rata berat pipilan kering per plot, berat 100 biji, dan nilai indeks panen pada varietas yang berbeda

\begin{tabular}{lccc}
\hline \multicolumn{1}{c}{ Variabel } & \multicolumn{3}{c}{ Varietas } \\
\cline { 2 - 4 } & ABCD & EFGH & IJKL \\
\hline $\begin{array}{l}\text { Berat pipilan } \\
\text { kering per plot } \\
\text { (kilogram) }\end{array}$ & $6,84^{\mathrm{a}}$ & $7,50^{\mathrm{b}}$ & $7,31^{\mathrm{b}}$ \\
$\begin{array}{l}\text { Berat 100 biji } \\
\text { jagung (gram) }\end{array}$ & $28,25^{\mathrm{a}}$ & $31,08^{\mathrm{b}}$ & $32,36^{\mathrm{b}}$ \\
$\begin{array}{l}\text { Nilai Indeks } \\
\text { Panen }\end{array}$ & $0.40^{\mathrm{a}}$ & $0.41^{\mathrm{a}}$ & $0.41^{\mathrm{a}}$ \\
\hline
\end{tabular}

Keterangan: Angka yang diikuti huruf sama pada baris menunjukkan tidak beda nyata berdasarkan DMRT taraf $5 \%$

Hasil penelitian menunjukkan bahwa varietas berpengaruh terhadap berat pipilan kering dan berat 100 biji. Sejalan dengan Ali et al. (2012) bahwa varietas hibrida mempunyai potensi hasil yang lebih tinggi dibandingkan dengan varietas lokal dan bersari bebas sebagai efek heterosis pada jagung hibrida. Menurut Rahni (2012) berat 100 biji menggambarkan ukuran besar dan bernasnya biji dan merupakan salah satu indikator kualitas biji. Semakin tinggi nilai berat kering 100 biji maka semakin berkualitas biji. Indeks panen menunjukkan proporsi bobot panen dari bobot tanaman secara keseluruhan (Johnson et al. 1986). Omondi et al. (2014) mengungkapkan indeks panen yang tingg akan mempengaruhi jumlah hasil panen yang besar dan produktivitas kecil mempengaruhi hasil panen yang kecil. Nilai indeks panen menurun apabila kerapatan populasi tanaman jagung meningkat. Hal ini karena akumulasi biomassa yang lebih besar pada bagian vegetatif tanaman (Dobermann et al. 2002).

Tabel 7 Rata-rata berat pipilan kering per plot, berat 100 biji dan nilai indeks panen pada pemberian dosis pupuk fosfat

\begin{tabular}{lccc}
\hline \multirow{2}{*}{ Variabel } & \multicolumn{3}{c}{$\begin{array}{c}\text { Dosis Pupuk Fosfat } \\
\text { (kilogram ha }{ }^{-1} \text { ) }\end{array}$} \\
\cline { 2 - 4 } & 0 & 100 & 150 \\
\hline Berat pipilan kering & $6,83^{\mathrm{a}}$ & $7,24^{\mathrm{b}}$ & $7,58^{\mathrm{c}}$ \\
per plot (kilogram) & $29,12^{\mathrm{a}}$ & $29,59^{\mathrm{a}}$ & $32,98^{\mathrm{b}}$ \\
Berat 100 biji (gram) & $0.40^{\mathrm{a}}$ & $0.41^{\mathrm{a}}$ & $0.41^{\mathrm{a}}$ \\
Nilai Indeks Panen & 0.4
\end{tabular}

Keterangan: Angka yang diikuti huruf sama pada baris menunjukkan tidak beda nyata berdasarkan uji DMRT taraf $5 \%$

Hasil menunjukkan bahwa dosis pupuk fosfat dapat meningkatkan berat pipilan kering dan berat 100 biji. Dosis 150 kilogram ha $^{-1}$ menunjukkan hasil yang paling tinggi baik pada berat pipilan kering dan berat
100 biji. Goenadi et al. (2000) mengemukakan bahwa besarnya pengaruh terhadap kelarutan $P$ atau peningkatan pertumbuhan/hasil tanaman dipengaruhi oleh berbagai faktor antara lain sumber fospat. Variabel selanjutnya adalah indeks panen dimana diperoleh hasil bahwa pemberian dosis pupuk fosfat tidak dapat meningkatkan nilai indeks panen. Ketiga varietas memiliki nilai indeks panen dengan rentang yang sama yaitu 0,40 pada ABCD dan 0,41 pada EFGH dan IJKL. Menurut Efendi dan Suwardi (2010), indeks panen merupakan rasio berat biji dengan berat biomas. Semakin tinggi indeks panen tanaman jagung menunjukkan bahwa partisi fotosintat di tajuk banyak ditranslokasi ke bagian biji.

\section{Berat brangkasan segar dan kering}

Brangkasan tanaman merupakan ukuran yang paling sering digunakan untuk mendiskripsikan dan mengetahui pertumbuhan suatu tanaman. Hasil analisis ragam menunjukkan bahwa berat brangkasan segar jagung dipengaruhi oleh semua faktor perlakuan yang dicobakan dan terdapat interaksi keduanya.

Tabel 8 Rata-rata berat pipilan kering per plot dan berat 100 biji jagung pada tiga varietas jagung hibrida

\begin{tabular}{cccc}
\hline Dosis pupuk & \multicolumn{3}{c}{ Varietas } \\
\cline { 2 - 4 } $\begin{array}{c}\text { fosfat } \\
\text { (kilogram }^{\left.\text {ha }^{-1}\right)}\end{array}$ & ABCD & EFGH & IJKL \\
\hline 0 & $178,30^{\text {a }}$ & $306,39^{\text {cd }}$ & $271,92^{\text {bc }}$ \\
100 & $247,28^{\text {b }}$ & $312,28^{\text {cd }}$ & $296,17^{\text {bcd }}$ \\
150 & $291,69^{\text {bcd }}$ & $336,06^{\text {d }}$ & $290,89^{\text {bcd }}$ \\
\hline
\end{tabular}

Keterangan: Angka yang diikuti huruf sama pada baris menunjukkan tidak beda nyata berdasarkan uji DMRT taraf $5 \%$

Berat brangkasan segar varietas EFGH dengan pemberian dosis 150 kilogram ha $^{-1}$ menunjukkan ratarata tertinggi (336,06 gram) dan rata-rata terendah diperoleh varietas $A B C D$ dengan pemberian dosis 0 kilogram/ha $\quad(178,30 \quad$ gram $)$. Derera et al. (2006) dan Machida et al. (2014) melaporkan bahwa varietas unggul jagung hibrida menghasilkan biomas tinggi.

Tabel 9 Rata-rata berat brangkasan kering jagung pada varietas dan pemberian dosis pupuk fosfat yang berbeda

\begin{tabular}{cccc}
\hline Dosis pupuk & \multicolumn{3}{c}{ Varietas } \\
\cline { 2 - 4 } fosfat \\
(kilogram/ha) & ABCD & EFGH & IJKL \\
\hline 0 & $114,58^{\mathrm{a}}$ & $210,45^{\mathrm{c}}$ & $159,97^{\mathrm{b}}$ \\
100 & $191,66^{\mathrm{bc}}$ & $205,38^{\mathrm{bc}}$ & $175,90^{\mathrm{bc}}$ \\
150 & $177,13^{\mathrm{bc}}$ & $213,58^{\mathrm{c}}$ & $182,33^{\mathrm{bc}}$ \\
\hline
\end{tabular}

Keterangan: Angka yang diikuti huruf sama pada baris menunjukkan tidak beda nyata berdasarkan uji DMRT taraf $5 \%$ 
Berat brangkasan kering varietas EFGH dengan dosis 150 kilogram ha ${ }^{-1}$ memiliki rata-rata berat brangkasan kering tertinggi (213,58 gram) dan rata-rata berat brangkasan kering terrendah terdapat pada varietas $A B C D$ dengan pemberian dosis 0 kilogram ha $(114,58 \mathrm{gram})$, hal ini serupa dengan hasil rata-rata berat brangkasan segar. Sejalan dengan Schroeder et al. (2013) menyatakan bahwa peningkatan produktivitas jagung dapat dicapai dengan meningkatnya penggunaan teknik produksi modern seperti penerapan varietas jagung hibrida dan aplikasi pupuk.

\section{Hasil panen per hektar}

Varietas dan dosis pupuk fosfat memberikan pengaruh terhadap hasil pipilan kering per hektar, seperti terlihat pada gambar berikut.

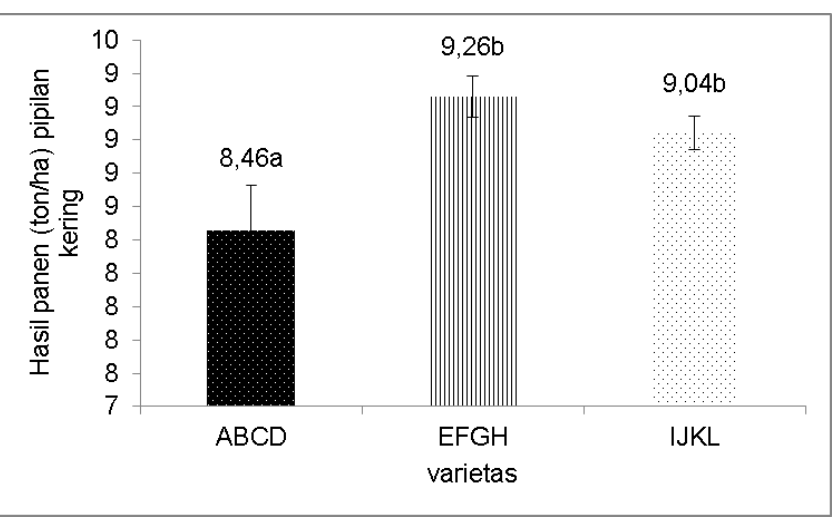

Gambar 3. Pengaruh perlakuan varietas terhadap hasil pipilan kering per hektar

Hasil penelitian menunjukkan bahwa varietas berpengaruh terhadap hasil pipilan kering per hektar. Varietas EFGH dan IJKL memiliki rentang nilai rata-rata hasil panen pipilan kering yang tinggi yaitu 9,26 ton/ha dan 9,04 ton ha ${ }^{-1}$. Sejalan dengan pernyataan Govind et al. (2015) bahwa penelitian dalam bidang perbanyakan varietas baru yang unggul salah satunya hibrida dengan pemuliaan tanaman merupakan salah satu cara untuk meningkatkan produktivitas hasil. Potensi hasil yang tinggi juga merupakan parameter penentu adopsi varietas unggul jagung oleh petani (Kudi et al. 2011).

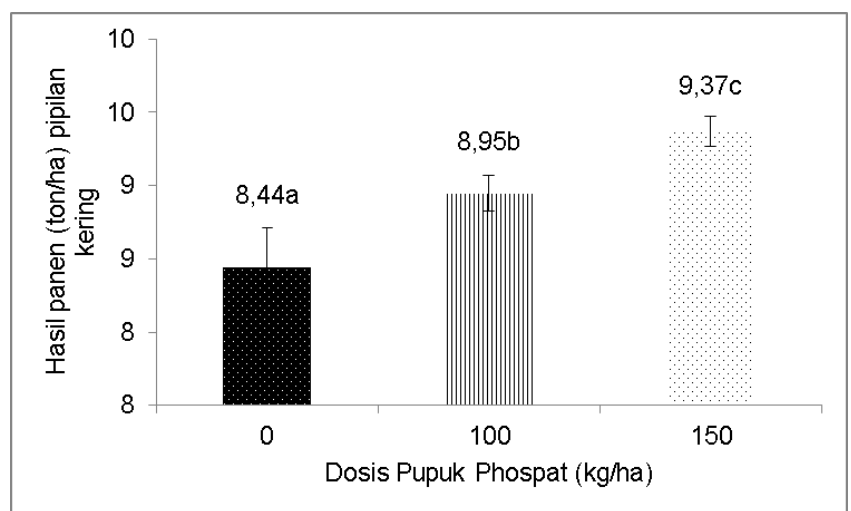

Gambar 4. Pengaruh perlakuan pemberian dosis pupuk fosfat terhadap hasil pipilan kering per hektar
Hasil penelitian menunjukkan bahwa dosis pupuk fosfat dapat meningkatkan hasil pipilan kering per hektar. Pemberian dosis pupuk fosfat 150 kilogram ha $^{-1}$ memberikan hasil panen pipilan kering tertinggi juga yaitu 9,37 ton ha ${ }^{-1}$ diikuti dosis 100 kilogram ha $^{-1}$ sebesar 8,95 ton ha $^{-1}$ dan terrendah pada pemberian dosis pupuk fosfat 0 kilogram ha ${ }^{-1}$ yaitu diperoleh 8,44 ton/ha. Menurut Witt et al (2006), kebutuhan hara akan tanaman jagung dipengaruhi oleh respons hasil terhadap pemupukan dan efisiensi penggunaan pupuk. Sejalan dengan Isrun (2006) yang menyatakan bahwa hasil tanaman jagung terus meningkat seiring dengan meningkatnya dosis pupuk fosfat yang diberikan ke dalam tanah.

\section{KESIMPULAN}

Berdasarkan hasil penelitian dapat diambil kesimpulan bahwa:

1. Pupuk $P(S P 36)$ meningkatkan hasil jagung 9,37 ton ha $^{-1}$

2. Dosis optimum untuk pertumbuhan dan hasil jagung adalah 150 kilogram/ha pada masing-masing varietas (ABCD, EFGH dan IJKL).

3. Varietas EFGH dengan dosis pupuk fosfat 150 kilogram ha $^{-1}$ merupakan perlakuan yang paling sesuai untuk meningkatkan hasil jagung hibrida.

\section{DAFTAR PUSTAKA}

Agrita, Dita A. 2012. Pengaruh Kombinasi Dosis Pupuk Fosfat dengan Pupuk Kotoran Ayam terhadap Pertumbuhan dan Hasil Tanaman Jagung (Zea mays L.) Hibrida Varietas Bisi-2 Sumedang: Inceptisol Jatinangor.

Ali F, Shah IA, and Noor M. 2012. Heterosis for yield and agronomic attributes in diverse maize germplasm. AJCS 6(3): 455-46.

Amir L, Arlinda S, Fatmah H, Oslan J. 2012. Ketersediaan Nitrogen Tanah dan Pertumbuhan Tanaman Bayam (Amaranthus tricolor L.) yang Diperlukan dengan Pemberian Pupuk Kompos Azolla. J Sainsmat (2): 167-180

Bakhri S. 2007. Budidaya Jagung Dengan Konsep Pengelolaan Tanaman Terpadu (PTT). Sulawesi Tengah: Balai Pengkajian Teknologi Pertanian (BPTP).

Balai Penelitian Tanah. 2009. Petunjuk Teknis Analisis Kimia Tanah, Tanaman, Air dan Pupuk. Balai Penelitian Tanah. Departemen Pertanian Bogor: Badan Penelitian dan Pengembangan Pertanian.

Banziger, M., F.J. Betran, and H.R. Lafitte. 1997. Efficiency of high-nitrogen selection environments for im-proving maize for low nitrogen target environments. Crop Sci. 37:1103-1109.

Derera J, Tongoona., and B. Viver. 2006. Farmer perception on maize cultivar in the marginal eastern belt of Zimbabwe and their implications for breeding. African Crop Science Journal 14(1):1-15. 
[Deptan] Departemen Pertanian. 2006. http: //www.deptan.go.id. Diakses 25 April 2017.

Dierolf T, Fairhurst T, and Muterte. 2001. Soil fertility kit. A toolkit for acid, upland soil fertility management in Southeast Asia. First edition. Printed by Oxford Graphic Printers.

Efendi R dan Suwardi. 2010. Respon Tanaman Jagung Hibrida terhadap Tingkat Takaran Pemberian Nitrogen dan Kepadatan Populasi. Balai Penelitian Tanaman Serealia. Prosiding Pekan Serealia Nasional.

Goenadi, H.D., Siswanto dan Y. Sugianto. 2000. Bioactivation of poorly Soluble Phosphate Roctiswite a Phosphate Solubilizing Fungis. Soil Sci. Soc. Am. J64: 927-932.

Hartanto S. 2009. Penerapan SNI produk pupuk fosfat alam untuk pertanian oleh industri. Peneliti pada Bidang Sarana Riset dan Standardisasi. Bogor: Balai Besar Industri Agro.

Idawati A, Haryanto, dan Rasjid H. 1996. Serapan hara dan Pertumbuhan Padi Sawah Sehubungan dengan status Unsur Hara P pada Tanah Pustaka Negara. Batan: Pusat Aplikasi Isotop dan Radiasi.

Isrun. 2006. Pengaruh Dosis Pupuk P dan Jenis Pupuk Kandang Terhadap Beberapa Sifat Kimia Tanah, Serapan $\mathrm{P}$ dan hasil Jagung Manis (Zea mays var Saccharata sturt) Pada Inceptisols Jatinangor. J Agrisains 7(1):9-17

Kudi TM, Bolaji, and Nasa IDH. 2011. Analysis of adoption of improved maize varieties among farmers in Kwara State, Negeria. International Journal of Peace and Development Studies 1(3): 8-12.

Kusnadi H. 2000. Kamus Istilah Pertanian. Yogyakarta: Penerbit Kanisius.

Machida L, Langyintuo, and MacRobert. 2014. Exploration of farmers' preferences and perceptions of maize varieties: implications on development and adoption of quality protein maize (QPM) varieties in Zimbabwe. Journal of Sustainable Development 7(2): 194-207.
O'Neill, P.M., J.F. Shanahan, J.S. Schepers, and B. Cald-well. 2004. Agronomic responses of corn hybrids from different eras to deficit and edequate levels of water and nitrogen. Agron. J. 96:18801667.

Rahni M. 2012. Efek Fitohormon PGPR Terhadap Pertumbuhan Tanaman Jagung (Zea mays). J Agribisnis dan Pengembangan Wilayah 3(2): 2735.

Salisbury FB. dan Ross CW. 1992. Fisiologi Tumbuhan. Bandung: Institut Teknologi Bandung.

Schroeder R, A. Barta, and K Semrad. 2013. Strategies for RNA folding and assembly. Nature Rev. Mol. Cell Biol. 5:908-919.

Shancez PA. 1992. Sifat dan Pengolahan Tanah Tropika. Terjemahan: Jayadinata, Jilid I. Bandung: ITB.

Sitompul SM dan Guritno B. 1995. Analisis Pertumbuhan Tanaman. Yogyakarta: Gadjah Mada University Press.

Subekti A, Syafruddin, Efendi R, dan Sunarti. 2007. Morfologi tanaman dan fase pertumbuhan jagung. Maros: Balai Penelitian Tanaman Serealia.

Sutoro, Yoyo dan Iskandar. 1988. Budidaya Tanaman Jagung. Bogor: Balai Penelitian Tanaman Pangan.

Syariefa E. 2002. Menanti Jagung (Tepung) di Kebun Kita. Trubus. 390:69

Tahir, M., Tanveer, A., Ali, A., Abbas, M. And Wasaya, A. 2008. Comparative Yield Performance of Different Maize (Zea mays L.) Hybrids under Local Conditions of Faisalabad-Pakistan. Pakistan Journal of Life and Social Sciences. 6(2): 118-120.

Wardhani K. dan Musofie. 2009. Jerami Jagung Segar, Kering, dan Teramoniasi sebagai Pengganti Hijauan pada Sapi Potong. J Ilmiah Penelitian Ternak Gratis 2 (1): 1-5.

Winks I. 1990. Phosphorus and beef production in Northern Australia. Responses to phos-phorus by ruminants a review. Trop. Grassid.

Witt, C., J. M. Pasuquin., and A. Dobermann. 2006. To wards a site-specific nutrient management approach for maize in Asia. Better Crops, 90:2831. 